\title{
Heavy Metal Contamination in Agricultural Soil at DEPZA, Bangladesh
}

\author{
Md Tanvir Hasnine ${ }^{1}$, Md Emadul Huda ${ }^{1}$, Rajada Khatun ${ }^{2, *}$, A H M Saadat ${ }^{1}$, Monjur Ahasan ${ }^{2}$, \\ Shirin Akter², Md Fakhar Uddin², Ashrafun Nahar Monika', M Ashikur Rahman', Md Ohiduzzaman ${ }^{3}$ \\ ${ }^{1}$ Department of Environmental Sciences, Jahangirnagar University, Savar, Dhaka, Bangladesh \\ ${ }^{2}$ Medical Physics Research Group, Atomic Energy Centre, 4 Kazi Nazrul Islam Avenue, Shahbag, Dhaka, Bangladesh \\ ${ }^{3}$ Department of Physics, Jessore University of Science and Technology, Bangladesh
}

Copyright $\subset 2017$ by authors, all rights reserved. Authors agree that this article remains permanently open access under the terms of the Creative Commons Attribution License 4.0 International License

\begin{abstract}
Higher accumulation of toxic heavy metals in rice grown in agricultural soil may lead to health disorder. The present study was carried out to assess the levels of different heavy metals like potassium, calcium, titanium, vanadium, chromium, manganese, iron, cobalt, nickel, copper and zinc in agricultural soil. The soil samples were collected by soil auger from the arable fields of Nolam near Dhaka Export Processing Zone Area (DEPZA), Savar, Dhaka of Bangladesh. The samples were irradiated using $3 \mathrm{MV}$ Van de Graaff Accelerator at the Atomic Energy Centre, Dhaka and Proton Induced X-ray Emission (PIXE) technique was employed for the analysis. The results indicated a substantial build-up of heavy metals in surface soil andsub-surface soil. Average metal concentrations were calculated and compared with reference values. The persistence of heavy metals in surface soil was higher than the sub-surface soil and it exceeded the standard safe limit. Uptake and translocation factor of heavy metal from surface soil to sub-surface soil were quite distinguished for almost all elements examined. In terms of health risk, the observed highest concentrations of these elements in soil could have an effect on human health which may pose public health hazards and for this pretreatment process of waste water is necessary for reducing the amount of heavy metals before using it to the agricultural soil. Wastewater from industries or other sources carries an appreciable amount of toxic heavy metals therefore their discharge into the environment must be minimized and carefully controlled.
\end{abstract}

Keywords Toxic, Accumulation, Heavy Metal, Pretreatment

\section{Introduction}

Heavy metal pollution of agricultural soil and vegetables is one of the most severe ecological problems on a world scale and also in Bangladesh. Use of wastewater to irrigate agricultural lands is a common practice in suburban and industrial areas in many parts of the world. Wastewater carries appreciable amounts of trace toxic metals which often lead to degradation of soil health and contamination of food chain mainly through the vegetable grown on such soils. In Bangladesh, there are many industries in and around DEPZA, mainly textiles which discharge heavy metals like cadmium, lead, chromium, mercury, zinc, arsenic and in a few cases copper and manganese with their effluents and wastes. These metals are toxic and even in trace amounts, interfere with or inactivate enzymes of living cells. Bangladesh has a limited capacity for waste treatment and recycling facilities; untreated wastes are often disposed of and/or discharged onto nearby agricultural land, into canals and streams, along roadsides and in the vicinity of residential areas without any treatments. Unregulated disposal of wastes has become a routine practice in the major cities of Bangladesh [1].

Heavy metals are currently of much environmental concern. They are harmful to humans, animals and are susceptible to bioaccumulation in the food chain. Heavy metals are known as non-biodegradable, and persist for long durations in aquatic as well as terrestrial environments. They might be transported from soil to ground waters or may be taken up by plants, including agricultural crops. For this reason, the knowledge of metal-plant interactions is also important for the safety of the environment.

Excessive accumulation of trace elements in agricultural soils through wastewater irrigation may not only result in soil contamination but also affect food quality and safety. There is evidence to indicate that agricultural soil have increased levels of heavy metals as a results of increased in anthropogenic activities [2]. Industrial waste has been implicated as a potential source of heavy metals such as Copper (Cu), Cadmium (Cd), Zinc ( $\mathrm{Zn}$ ), Lead (Pb), Nickel (Ni) and Iron $(\mathrm{Fe})$ in the edible and non-edible parts of vegetables. Certain trace elements are essential in plant 
nutrition, but plants growing in a polluted environment can accumulate trace elements at high contaminations causing a serious risk to human health when they are consumed. These metals enter into air-soil-water systems, food crops and domestic animals, and ultimately affect public health via the food chain. Human diseases associated with excessive uptake of toxic heavy metals include cancer, gastrointestinal, pulmonary and kidney ailments [3].

In this study, the concentrations of $\mathrm{K}, \mathrm{Ca}, \mathrm{Ti}, \mathrm{V}, \mathrm{Cr}, \mathrm{Mn}$, $\mathrm{Fe}, \mathrm{Co}, \mathrm{Ni}, \mathrm{Cu}$ and $\mathrm{Zn}$ in 18 soils samples collected from Dhaka Export Processing Zone (DEPZ) were determined in order to provide information about the status of heavy metal pollution in soil of this region.

\section{Materials and Methods}

Samples were collected from an agricultural land of Nolam, Savar Upazila near Bangshi river of DEPZA which main source of irrigation is industrial waste water. Total 18 soil samples from nine locations were collected and each soil sample represents only one soil type or soil condition. Each sample consisted of a group of subsamples taken from 9 locations within a sampling area. Soil sample were taken to plough depth, i.e. from the surface down to about 12 inches and were collected by soil auger from the depth of $0-15 \mathrm{~cm}$ and $15-30 \mathrm{~cm}$ at surface level and prepared at the Accelerator Facilities Division of Atomic Energy Centre, Dhaka. Soil sampling site locations are given below:

Table 1. Soil sampling sites

\begin{tabular}{|c|c|c|}
\hline Sample No. & Latitude & Longitude \\
\hline S-1 & $23^{\circ} 56^{\prime} .678^{\prime \prime} \mathrm{N}$ & $90^{\circ} 14^{\prime} .012^{\prime \prime} \mathrm{E}$ \\
\hline S-2 & $23^{\circ} 56^{\prime} .680^{\prime \prime} \mathrm{N}$ & $90^{\circ} 13^{\prime} .993^{\prime \prime} \mathrm{E}$ \\
\hline S-3 & $23^{\circ} 56^{\prime} .697^{\prime \prime} \mathrm{N}$ & $90^{\circ} 14^{\prime} .008^{\prime \prime} \mathrm{E}$ \\
\hline S-4 & $23^{\circ} 56^{\prime} .690^{\prime \prime} \mathrm{N}$ & $90^{\circ} 13^{\prime} .99^{\prime \prime} \mathrm{E}$ \\
\hline S-5 & $23^{\circ} 56^{\prime} .704^{\prime \prime} \mathrm{N}$ & $90^{\circ} 13^{\prime} .988^{\prime \prime} \mathrm{E}$ \\
\hline S-6 & $23^{\circ} 56^{\prime} .71^{\prime \prime} \mathrm{N}$ & $90^{\circ} 13^{\prime} .985^{\prime \prime} \mathrm{E}$ \\
\hline S-7 & $23^{\circ} 56^{\prime} .72^{\prime \prime} \mathrm{N}$ & $90^{\circ} 13^{\prime} .988^{\prime \prime} \mathrm{E}$ \\
\hline S-8 & $23^{\circ} 56^{\prime} .720^{\prime \prime} \mathrm{N}$ & $90^{\circ} 14^{\prime} .006^{\prime \prime} \mathrm{E}$ \\
\hline S-9 & $23^{\circ} 56^{\prime} .73^{\prime \prime} \mathrm{N}$ & $90^{\circ} 14^{\prime} .012^{\prime \prime} \mathrm{E}$ \\
\hline
\end{tabular}

\subsection{Sample Preparation}

The collected samples were dried in an oven at a temperature of $600^{\circ} \mathrm{C}$ for about 10 hours to make the samples water free. After cooling the samples to the room temperature in a dessicator, the weights were taken. The process of heating, cooling and weighting was repeated until a constant weight is shown by the balance which is a confirmation of zero water content. The dried weighted samples were then ground in a grinder and made into pellets with a pellet maker. Special care has been taken during the whole process to avoid contamination during grinding, mixing or packaging. These pellets were used as the targets for irradiation with proton beam of energy $2.5 \mathrm{MeV}$.

\subsection{Standardization of the System}

Two standard samples were used for the purpose of quality control of the system adopted. Here Standard Reference Material 1633b (Coal Fly Ash) and IAEA standard soil-7 were used as standards in this experiment for the quality control of the measurement of elemental concentration of soil samples. They were irradiated with proton beams to reproduce the desired results. The certified reference values are compared with the measured values of the respective elements and found to be compatible $(\sim 10 \%)$.

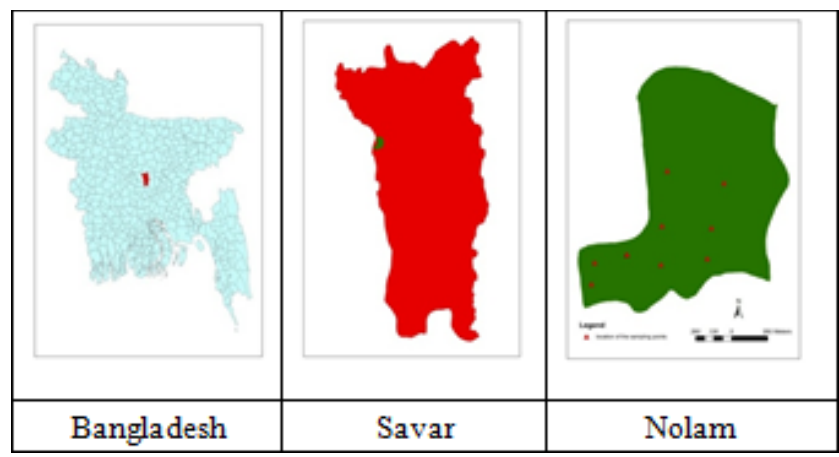

Figure 1. Location of sampling site (enlarged region)

\section{Result and Discussion}

\subsection{Average Metal Concentration of Surface and Sub-Surface soil}

Between surface and sub-surface soil it was found that the average concentration of metal in surface soil was higher than the sub-surface soil. The highest value was found for $\mathrm{Fe}$ both in surface and sub-surface soil of different sampling point. The average value for $\mathrm{Fe}$ in surface soil was 41502 $\mathrm{ppm}$ and in sub-surface soils the average value for $\mathrm{Fe}$ was 32589 ppm (Figure 2).

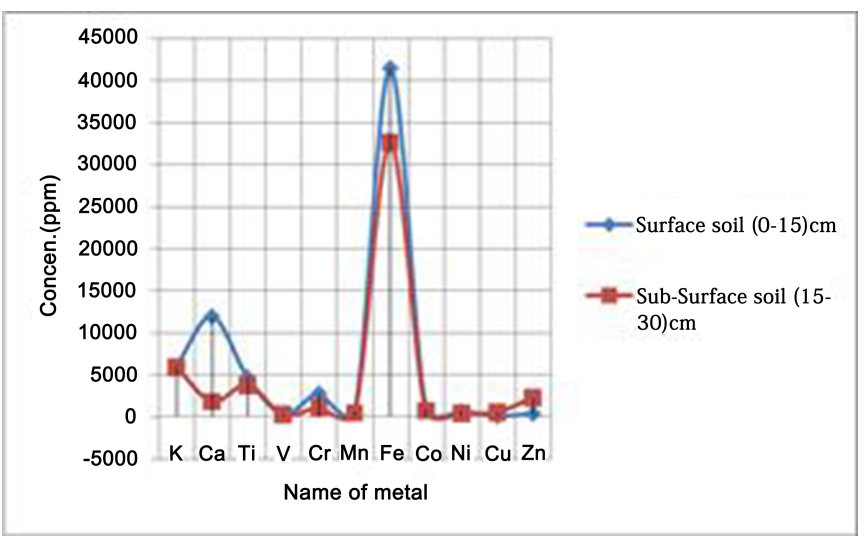

Figure 2. Average metal concentration (ppm) of surface \& sub-surface soil 


\subsection{Discussion}

The application of wastewater has led to changes in some soil physicochemical characteristics and heavy metal uptake by food crops, particularly vegetables. The soil $\mathrm{pH}$ changes depend on $\mathrm{pH}$ of the wastewater used for irrigation, and the soil $\mathrm{pH}$ has a great influence on the mobility and bioavailability of heavy metals [4]. Continuous wastewater irrigation led to elevated levels of heavy metals in the soils and in edible parts of food crops. Compared with standard regulatory limits set by different authors and also with WHO safe limit, the concentrations of heavy metals in studied soils were significantly higher than the reference soil, indicating that the wastewater irrigation has increased the heavy metal concentrations in soils.

Table 2(a). Soil Surface $(0-15 \mathrm{~cm})$ Correlation data

\begin{tabular}{|c|c|c|c|c|c|c|c|c|c|c|c|}
\hline & $\mathrm{K}$ & $\mathrm{Ca}$ & $\mathrm{Ti}$ & $\mathrm{V}$ & $\mathrm{Cr}$ & $\mathrm{Mn}$ & $\mathrm{Fe}$ & $\mathrm{Co}$ & $\mathrm{Ni}$ & $\mathrm{Cu}$ & $\mathrm{Zn}$ \\
\hline $\mathrm{K}$ & 1 & -.003 & -.325 & .006 & -.188 & -.507 & -.349 & -.168 & -.169 & -.530 & -.574 \\
\hline $\mathrm{Ca}$ & -.003 & 1 & -.270 & -.497 & .376 & .228 & .070 & .198 & .362 & -.274 & -.369 \\
\hline $\mathrm{Ti}$ & -.325 & -.270 & 1 & $.743^{*}$ & -.455 & -.386 & .271 & -.037 & -.485 & $.807^{* *}$ & $.889^{* *}$ \\
\hline $\mathrm{V}$ & .006 & -.497 & $.743^{*}$ & 1 & $-.906^{* *}$ & $-.748^{*}$ & -.353 & -.629 & $-.910^{* *}$ & .334 & .502 \\
\hline $\mathrm{Cr}$ & -.188 & .376 & -.455 & $-.906^{* *}$ & 1 & $.879^{* *}$ & $.706^{*}$ & $.878^{* *}$ & $.998^{* *}$ & .078 & -.117 \\
\hline $\mathrm{Mn}$ & -.507 & .228 & -.386 & $-.748^{*}$ & $.879^{* *}$ & 1 & .643 & $.714^{*}$ & $.874^{* *}$ & .185 & .033 \\
\hline $\mathrm{Fe}$ & -.349 & .070 & .271 & -.353 & $.706^{*}$ & .643 & 1 & $.936^{* *}$ & $.684^{*}$ & $.739^{*}$ & .570 \\
\hline $\mathrm{Co}$ & -.168 & .198 & -.037 & -.629 & $.878^{* *}$ & $.714^{*}$ & $.936^{* *}$ & 1 & $.864^{* *}$ & .466 & .264 \\
\hline $\mathrm{Ni}$ & -.169 & .362 & -.485 & $-.910^{* *}$ & $.998^{* *}$ & $.874^{* *}$ & $.684^{*}$ & $.864^{* *}$ & 1 & .051 & -.143 \\
\hline $\mathrm{Cu}$ & -.530 & -.274 & $.807^{* *}$ & .334 & .078 & .185 & $.739^{*}$ & .466 & .051 & 1 & $.969 * *$ \\
\hline $\mathrm{Zn}$ & -.574 & -.369 & $.889 * *$ & .502 & -.117 & .033 & .570 & .264 & -.143 & $.969^{* *}$ & 1 \\
\hline
\end{tabular}

Table 2(b). Soil Surface $(15-30 \mathrm{~cm})$ Correlation data

\begin{tabular}{|c|c|c|c|c|c|c|c|c|c|c|c|}
\hline & $\mathrm{K}$ & $\mathrm{Ca}$ & $\mathrm{Ti}$ & $\mathrm{V}$ & $\mathrm{Cr}$ & $\mathrm{Mn}$ & $\mathrm{Fe}$ & $\mathrm{Co}$ & $\mathrm{Ni}$ & $\mathrm{Cu}$ & $\mathrm{Zn}$ \\
\hline $\mathrm{K}$ & 1 & .308 & .545 & $-.837^{* *}$ & $.796^{*}$ & $.749^{*}$ & $.879^{* *}$ & $.941^{* *}$ & $.764^{*}$ & $-.777^{*}$ & $-.780^{*}$ \\
\hline $\mathrm{Ca}$ & .308 & 1 & .408 & -.183 & .465 & $.686^{*}$ & -.123 & .077 & .390 & -.238 & -.162 \\
\hline $\mathrm{Ti}$ & .545 & .408 & 1 & -.255 & .495 & .505 & .316 & .448 & .497 & -.416 & -.382 \\
\hline $\mathrm{V}$ & $-.837^{* *}$ & -.183 & -.255 & 1 & $-.920^{* *}$ & $-.817^{* *}$ & $-.890^{* *}$ & $-.876^{* *}$ & $-.917^{* *}$ & .502 & .539 \\
\hline $\mathrm{Cr}$ & $.796^{*}$ & .465 & .495 & $-.920^{* *}$ & 1 & $.960^{* *}$ & $.723^{*}$ & $.774^{*}$ & $.993^{* *}$ & -.437 & -.451 \\
\hline $\mathrm{Mn}$ & $.749^{*}$ & $.686^{*}$ & .505 & $-.817^{* *}$ & $.960^{* *}$ & 1 & .555 & .648 & $.933^{* *}$ & -.405 & -.393 \\
\hline $\mathrm{Fe}$ & $.879^{* *}$ & -.123 & .316 & $-.890^{* *}$ & $.723^{*}$ & .555 & 1 & $.964^{* *}$ & $.729^{*}$ & -.652 & $-.702^{*}$ \\
\hline $\mathrm{Co}$ & $.941^{* *}$ & .077 & .448 & $-.876^{* *}$ & $.774^{*}$ & .648 & $.964^{* *}$ & 1 & $.757^{*}$ & $-.802^{* *}$ & $-.834^{* *}$ \\
\hline $\mathrm{Ni}$ & $.764^{*}$ & .390 & .497 & $-.917^{* *}$ & $.993^{* *}$ & $.933^{* *}$ & $.729^{*}$ & $.757^{*}$ & 1 & -.366 & -.387 \\
\hline $\mathrm{Cu}$ & $-.777^{*}$ & -.238 & -.416 & .502 & -.437 & -.405 & -.652 & $-.802^{* *}$ & -.366 & 1 & $.993^{* *}$ \\
\hline $\mathrm{Zn}$ & $-.780^{*}$ & -.162 & -.382 & .539 & -.451 & -.393 & $-.702^{*}$ & $-.834^{* *}$ & -.387 & $.993^{* *}$ & 1 \\
\hline
\end{tabular}

$* *$ Correlation is significant at the 0.01 level (2-tailed)

* Correlation is significant at the 0.05 level (2-tailed)

a. List wise $\mathrm{N}=9$

Table 3. Standard regulatory limits/ background levels of metals in soil

\begin{tabular}{|c|c|c|}
\hline Name of metals & $\begin{array}{l}\text { Concentration } \\
\left(\mathrm{ppm} \text { or } \mathrm{mgkg}^{-1}\right)\end{array}$ & Reference \\
\hline Chromium (Cr) & $<1-100 \mathrm{mg} / \mathrm{kg}$ & 5 \\
\hline Cobalt (Co) & $1-40 \mathrm{mg} / \mathrm{kg}$ & 5 \\
\hline Copper $(\mathrm{Cu})$ & $20-30 \mathrm{mg} / \mathrm{kg}$ & 5 \\
\hline Manganese (Mn) & $80-7000 \mathrm{mg} / \mathrm{kg}$ & 5 \\
\hline Nickel (Ni) & $\begin{array}{c}5-500 \mathrm{mg} / \mathrm{kg} \text { (average } 50 \mathrm{mg} / \mathrm{kg} \text { ) } \\
40 \mathrm{mg} / \mathrm{kg}\end{array}$ & $\begin{array}{l}6 \\
5\end{array}$ \\
\hline Zinc $(\mathrm{Zn})$ & $10-300 \mathrm{mg} / \mathrm{kg}(50 \mathrm{mg} / \mathrm{kg}$ average $)$ & 5 \\
\hline
\end{tabular}




\subsubsection{Potassium}

The average concentration of potassium was $6018.1 \pm$ $1964.86 \mathrm{ppm}$ in the surface soil whereas; in the sub-surface layer the average concentration was $5854.8 \pm 968.69 \mathrm{ppm}$. Concentration of K in surface soil ranged from 3191 to 9589 ppm whereas the concentration in sub-surface soil ranged from 4892 to $7371 \mathrm{ppm}$. This may due to haphazard distribution of industrial effluent.

Excessive quantities of $\mathrm{K}$ in soils can lead to $\mathrm{K}$ losses off site through leaching into groundwater or surface runoff [7]. Although $\mathrm{K}$ is largely retained in soils, it can leach from coarse, sandy, well drained soils, where loadings are excessive or through bypass flow mechanisms. Higher concentrations of $\mathrm{K}$ in surface runoff or leachate are associated with sites with a high use of $\mathrm{K}$ fertilizer or effluent application, especially where soil incorporation does not occur [8]. The amount of natural $\mathrm{K}$ and the amount of $\mathrm{K}$ from effluent or fertilizer which is or becomes available for plants depends on a soils' physical and chemical parameters, including particle size, clay mineralogy, moisture status, organic matter and soil $\mathrm{pH}[9]$.

\subsubsection{Calcium}

Calcium is a dietary requirement for all organisms apart from some insects and bacteria. In this study, the average concentration of Calcium was $11937 \pm 6651.43 \mathrm{ppm}$ in the surface soil whereas; this value for sub surface layer was $1767.2 \pm 1113.96 \mathrm{ppm}$. Calcium level ranged from 1844 to $21808 \mathrm{ppm}$ in the surface soil and in sub-surface the concentration ranged from 935 to $4069 \mathrm{ppm}$. From the study, it seems that in surface soil the concentration of $\mathrm{Ca}$ was too high rather than the sub-surface soil. Calcium often positively affects soil quality and various compounds are applied as a fertilizer. For example, $\mathrm{CaCl}_{2}$ or $\mathrm{Ca}(\mathrm{NO})_{3}$ solutions are applied in horticulture. Calcium carbonate is a building stone of skeletons of most marine organisms, and eye lenses. Calcium phosphate is required for bone structure and teeth structure of terrestrial organisms.

\subsubsection{Titanium}

Titanium level ranged from $2958 \mathrm{ppm}$ to $8335 \mathrm{ppm}$ in the surface soil and, the average concentration was 4682.9 $\pm 1520.20 \mathrm{ppm}$. In sub-surface soil, the concentration ranged from 3274 to $4297 \mathrm{ppm}$ whereas the average was $3730.6 \pm$ $331.38 \mathrm{ppm}$. It seems that the average concentration of titanium was so high in the surface soil rather than the sub-surface. Titanium is present in soil in a relatively high concentration within the range from several tenths of percent up to several percentage points. Ti is generally present in most plants in relatively low concentrations $(0.1-10 \mathrm{ppm})$ but there is no evidence about the essential participation of naturally occurred $\mathrm{Ti}$ in plant metabolism [10].

\subsubsection{Vanadium}

In the surface soil, the average concentration of vanadium was $265.82 \pm 163.59 \mathrm{ppm}$ whereas; this value for sub surface layer was $198.42 \pm 55.24 \mathrm{ppm}$. Vanadium levels in surface soil ranged from 0 to $494.8 \mathrm{ppm}$ and in sub-surface soil the range was from 105.4 to $278.9 \mathrm{ppm}$.

Krishna et al. (2004) reported that the vanadium content of soil depends upon the parent material and the pedogenic process associated with its development [11]. Composition of the parent material has less bearing on $\mathrm{V}$ content of mature, developed soils. Normal threshold value for vanadium in soils is $100 \mathrm{mg} / \mathrm{kg}$. Compared with the normal threshold value, it can be said that the study area soil is 2 times greater than the normal standard. Vanadium usually has a wide and varied industrial usage in dyeing, textile, metallurgy and electronics. As majority of the industries are textile and petroleum products, which clearly indicates that the source is to be anthropogenic from industries in the area. According to Davis et al., Trace concentrations of vanadium have been reported to benefit plant growth, while higher concentrations are toxic [12].

\subsubsection{Chromium}

In this study, Chromium average concentration was found to be $2753.2 \pm 4598.86 \mathrm{ppm}$ in the surface soil whereas; this value for sub surface layer was $1039.2 \pm 1763.69 \mathrm{ppm}$. Between the two layers, the highest value was $11212 \mathrm{ppm}$ in the surface soil and the lowest value was $68.82 \mathrm{ppm}$ in the Sub-surface soil. The soil was contaminated with $\mathrm{Cr}$ as it exceeded the Standard regulatory limits reported by Alloway (1990). Chromium concentrations in Canadian soils ranged from 5 to $1,500 \mathrm{mg} / \mathrm{kg}$, with a mean of $43 \mathrm{mg} / \mathrm{kg}$ [13]. On a worldwide basis, the disposal of commercial products that contain chromium may be the largest Contributor, accounting for $51 \%$ of the total chromium released to soil. Other significant sources of chromium release into soil include the disposal of coal fly ash and bottom fly ash from electric utilities and other industries (33.1\%), agricultural and food wastes (5.3\%), animal wastes $(3.9 \%)$, and atmospheric fallout (2.4\%) [14]. Chromium enters the food chain through consumption of plant material and high concentration of $\mathrm{Cr}$ has been found to be harmful to vegetation. As the chromium concentration in plants increases, it adversely affects several biological parameters.

\subsubsection{Manganese}

The average concentration of Manganese was $577.52 \pm$ $465.70 \mathrm{ppm}$ in the surface soil whereas; this value for sub surface layer was $401.21 \pm 300.38 \mathrm{ppm}$. Manganese level ranged from 0 to $1311 \mathrm{ppm}$ in the surface soil whereas in the sub-surface soil the concentration was from 199.1 to 1083 $\mathrm{ppm}$. In the surface layer, the average concentration of $\mathrm{Mn}$ was higher than the sub-surface soil. But the regulatory limit of Mn insoil is from 80 to $7000 \mathrm{mg} / \mathrm{kg}$ set by Alloway, 1990 . In accordance with the standard of $\mathrm{Mn}$, it can be said that the amount of $\mathrm{Mn}$ both in surface and sub-surface soil was within safe limit. Law et al. (1998) reported that, Mn is important to ecosystem functioning [15]. The essentiality of Mn for living systems results from the fact that this metal is 
an essential cofactor for several classes of enzymes, such as oxidoreductases, transferases, ligases, or hydrolases.

\subsubsection{Iron}

In the surface soil, the average concentration of Iron was $41502 \pm 13203.39$ ppm whereas; this value for sub surface layer was $32589 \pm 8306.45 \mathrm{ppm}$. Between the two layers of different points, the highest value was found in surface soil \& it was $61331 \mathrm{ppm}$. The lowest value was found in Sub-surface soil \& it was $18869 \mathrm{ppm}$. In the surface soil, the range of Iron was from 28932 to $61331 \mathrm{ppm}$. On the other hand, in sub-surface soil it ranged from 18869 to $48729 \mathrm{ppm}$. From the report of Spectrum Analytic Inc, Iron toxicity is primarily $\mathrm{pH}$ related and occurs where the soil $\mathrm{pH}$ has dropped sufficiently to create an excess of available Iron. Fe toxicity can also occur when Zinc is deficient, or the soil is in a "reduced" condition caused by very wet or flooded conditions. Excess $\mathrm{Fe}$ can result in Dark green foliage, stunted growth of tops and roots, dark brown to purple leaves on some plants (e.g. bronzing disease of rice).

But according to van Breemen and Moormann (1978) [16] texture, cation exchange capacity, and organic matter content influence the concentration of ferrous iron in soil solution, in which iron toxicity occurs. Sahrawat (2004) [17] showed that, a high concentration of iron in soil solution can cause nutrient imbalance through antagonistic effects on the uptake of nutrients, including $\mathrm{K}$ and $\mathrm{Zn}$.

\subsubsection{Cobalt}

The average concentration of Cobalt was $1022.0 \pm 347.45$ $\mathrm{ppm}$ in the surface soil whereas; this value for sub surface layer was $704.30 \pm 269.36 \mathrm{ppm}$. Between the two layers, the highest value was found in surface soil \& it was $1586 \mathrm{ppm}$. The lowest value was found in Sub-surface soil \& it was 342 ppm. Compared with regulatory standards set by (Alloway, 1990) the concentration of $\mathrm{Cr}$ was so high. An increased amount of cobalt occurs, as well, as a result of industrial pollution. The cobalt concentrations in the surface and sub-surface levels of agricultural soils are relatively high and may indicate the influence of anthropogenic factors. Cobalt is easily absorbed by organic substances and creates organic chelates. These increase the mobility of cobalt and influence their mobility within the profile of the soils, and also increase its adaptability by plants, particularly in soils with an increased reactivity under oxidative conditions.

\subsubsection{Nickel}

In the surface soil, the average concentration of Nickel was $655.53 \pm 979.73 \mathrm{ppm}$ whereas; this value for sub surface layer was $377.01 \pm 418.34 \mathrm{ppm}$. Between the two layers, the highest value was found in surface soil \& it was $2566 \mathrm{ppm}$. The lowest value was also found in surface soil of different location \& it was $108.8 \mathrm{ppm}$.

According to, USPHS (1997), Alloway (1990) the average concentration of Nickel in soil is $50 \mathrm{mg} / \mathrm{kg}$. Compared with this value, the surface layer of the study area was 13 times higher than the standard value. On the other hand this value for sub-surface layer was 7 times higher than the regulatory standard. Baralkiewicz and Siepak (1999) [18] also worked on similar topics mentioned on their report that the solubility of nickel in soils increases with its acidity. Its sorption by hydroxides of iron and manganese increases with its drop in acidity. The concentration of nickel in soil solutions is in a range of several to several score but in polluted acidic soils it can be in excess of these values by many times. According to, Dojlido and Best (1993) [19] the greatest pollution of soils by nickel was found in the region of highly developed nickel smelting in Canada, approximately 26,000 mgkg-1, and in Great Britain, due to the use of communal waste for soil fertilization. Increased nickel content in Poland of 250 mgkg- 1 was determined in places polluted by galvanization plant sewage. This nickel can cause a variety of adverse effects on human health, such as nickel allergy in the form of contact dermatitis, lung fibrosis, cardiovascular and kidney diseases and cancer of the respiratory tract.

\subsubsection{Copper}

In this study, the average concentration of Copper was $91.06 \pm 152.70 \mathrm{ppm}$ in the surface soil whereas; this value for sub surface layer was $503.07 \pm 537.31 \mathrm{ppm}$. Among all the values of different location, the highest value was found in Sub-surface soil \& it was $1354 \mathrm{ppm}$. The lowest value was found in surface soil between the two layers \& it was $0 \mathrm{ppm}$. It is seen that the average concentration of Copper was maximum in the sub-surface layer. The regulatory standard of Copper in soil is $20-30 \mathrm{mg} / \mathrm{kg}$ [5]. Compared with this standard it is clear that the sub-surface zone is highly polluted by $\mathrm{Cu}$.

According to White and Brown (2010) [20] excessive soluble soil $\mathrm{Cu}$ can be toxic to plants, $\mathrm{Cu}$-enriched liquid dairy waste applied as irrigation water to agricultural crops raises concerns regarding how plants and soils are impacted. Sonmez et al. (2006) [21] studied the effect of increasing concentrations $(0,1000,2000 \mathrm{mg} / \mathrm{kg} \mathrm{Cu})$ to tomato (Lycopersicon esculentum (L.) Mill. Cv. F144), observing a decrease in plant height, total yield, number of fruit, and dry root weight with increasing $\mathrm{Cu}$ application. Not only are excessive $\mathrm{Cu}$ concentrations detrimental to plants, they may also toxic to microorganisms.

\subsubsection{Zinc}

The average concentration of Zinc was $378.45 \pm 807.71$ ppm in the surface soil whereas; this value for sub surface layer was $2216.6 \pm 2687.29 \mathrm{ppm}$. Between the two layers of all the sampling locations, the highest value was found in Sub-surface soil \& it was $6105 \mathrm{ppm}$. The lowest value was found in surface soil \& it was $38.18 \mathrm{ppm}$. But the average value of $\mathrm{Zn}$ in world soil is $45 \mathrm{ppm}$ and by Alloway (1990) the regulatory limit of $\mathrm{Zn}$ in soil is $50 \mathrm{mg} / \mathrm{kg}$. According to WHO (2007) [22], the concentration of $\mathrm{Zn}$ in wastewater irrigated soil is $300-600 \mathrm{mg} / \mathrm{kg}$ (dry soil). Compared with the entire standard, it can be said that the level of $\mathrm{Zn}$ exceed the 
permissible levels which indicate its abnormal condition. Though $\mathrm{Zn}$ is micronutrients but high concentrations in soils may be poisonous to micro-organisms, higher plants, and fauna. High concentrations of available zinc in soils usually arise from various sources of pollution, including: atmospheric deposition from a nearby industrial source, excessive applications of zinc rich materials and high zinc sewage sludge's or industrial waste waters. Alloway (2013) [23] reported that very high concentrations of zinc, such as $>$ $500 \mathrm{mg} / \mathrm{kg}$ Zn could cause some problems with yields, but it is unlikely that agricultural crops would be grown on significant areas of soils with such high concentrations. Elevated concentrations of zinc in crops probably do not constitute a toxicity hazard to humans or livestock consuming them but, it is often found that soils contaminated with zinc are also contaminated with non-essential trace elements including, cadmium and lead.

\subsection{Statistical Analysis}

Pearson correlation analysis was performed [24] between all the variables. The level of significance $(p \leq 0.05$ and $p \leq$ 0.01 ) of multi-element correlation for soil samples was determined and the results are given in Table 2 (a) and 2(b). The listed $r$ values indicated the high degree of positive correlations and significant linear relation between various pairs of metals, reflecting their simultaneous release and identical source from the DEPZ zone, transport and accumulation in soil. The strong association among the elements indicates common sources and these metals have been derived from anthropogenic sources, specially the paint industry and municipal sewage system.

\section{Conclusions}

There is no established tolerable/safe limit available for heavy metal in soil and crops of Bangladesh. Therefore, the levels of heavy metals found in different sources of the present study were compared with the prescribed safe limit provided by (WHO 2007) and other authors. The mean concentrations of heavy metals in soil were higher than the safe limits. However, $\mathrm{Co}, \mathrm{Fe}, \mathrm{Ni}, \mathrm{V}, \mathrm{Ti}, \mathrm{K}$ and $\mathrm{Cr}$ concentrations were above and for $\mathrm{Mn}$ it was equal to the safe limit set for the agricultural purpose by (WHO 2007). Concentrations of all the metals $(\mathrm{mg} / \mathrm{kg}$ dry weight $)$ in the studied agricultural soil were above the permissible level of different country standard. Among eleven heavy metals studied the concentration of $\mathrm{Fe}$ was maximum in soil. A summary of the results revealed that the relationship of heavy metal contamination of the soil with that of waste water is possibly complicated due to emission effects of different industries. The results of the present study show an analysis of heavy metal concentrations in soil around industrial areas of Bangladesh. Vegetables grown in this metal-contaminated soil may accumulate the metals in edible parts of plants. Long-term consumption of these metal-contaminated vegetables can cause different diseases like thalassemia, dermatitis, brain and kidney damage, and cancer in the human body. Hence regular monitoring of these toxic heavy metals from effluents and sewage, in soil is essential to prevent their excessive build up in the food chain.

\section{Acknowledgements}

The authors wish to thank all the members of Accelerator Facilities Division and Medical Physics Division for their continuous help during the course of this study.

\section{REFERENCES}

[1] M.A.Kashem, Singh B.R. Heavy metal contamination of soil and vegetation in the vicinity of industries in Bangladesh. Water, Air, Soil Pollut. Vol. 115, 347-361, 1999.

[2] R. K. Sharma, M. Agrawal \& F. Marshall. Heavy metal contamination of soil and vegetables in suburban areas of Varanasi, India. Ecotoxicology and Environmental Safety, Vol. 66, 258-266, 2007.

[3] A. Raymond, L. Wuana and E. Felix Okieimen. Heavy Metals in Contaminated Soils: A Review of Sources, Chemistry, Risks and Best Available Strategies for Remediation. International Scholarly Research Network. ISRN Ecology Vol. 20, 2011.

[4] R. Nigam, S. Srivastava, S. Prakash, M. M. Srivastava. Cadmium mobilization and plant availability-the impact of organic acids commonly exuded from roots. Plant and Soil, Vol. 230, 107-113, 2001.

[5] B. J. Alloway. Heavy metals in soils. John Wiley and Sons, Inc. New York, ISBN 0470215984, 1990.

[6] USPHS, Toxicological profile on CD-ROM. Agency for Toxic Substances and Disease Registry, 1997.

[7] G. Price. Australian soil fertility manual, CSIRO Publishing, Melbourne, 2006.

[8] M.R. McCaskill, A.M. Ridley, A. Okom, R.E. White, M.H. Andrew, D.L. Michalk, A. Melland, W.H.Johnston \& S.R. Murphy. 'SGS Nutrient Theme: environmental assessment of nutrient application to extensive pastures in the high rainfall zone of southern Australia', Australian Journal of Experimental Agriculture, Vol. 43(7-8), 927-944, 2003.

[9] W. J. Hosking. Potassium for Victorian Pastures - A Review, Department of Agriculture and Rural Affairs, Victoria, 1986.

[10] M.Carvajal, C.F. Alcaraz. Why is titanium a beneficial element for plants? Journal of Plant Nutrition, Vol. 21, 655-664, 1998.

[11] A.K. Krishna, P.K. Govil, \& G.L.N. Reddy. Soil contamination due to toxic metals in Talcher industrial area, Orissa, India. Journal of Applied Geochemistry, Vol. 6(1), 84-88, 2004. 
[12] M. J.Davis et al. Antigenic relationship of several rickettsia-like bacteria involved in plant disease. Proc. IV Int. Conf. Plant Path. Bact. Angers, France, 311-315. 1978.

[13] E. E. Cary. "Chromium in Air, Soil and Natural Waters", in: Topics in Environmental Health 5: Biological and Environmental Aspects of Chromium, S. Langard (ed.), Elsevier Science Publishers, New York, 49-64, 1982.

[14] J.O. Nriagu, and E. Nieboer. "Chromium in the Natural and Human Environments", in Advances in Environmental Science and Technology, John Wiley \& Sons, New York, Vol. 20, 785, 1988.

[15] N Law, M Caudle, V Pecoraro. Manganese redox enzymes and model systems: properties, structures, and reactivity. Adv Inorg Chem, Vol. 46, 305-440, 1998.

[16] N. Van Breemen, F. R. Moormann. Iron-toxic soils. In: Soils and rice. Manila (Philippines): International Rice Research institute, 781-800, 1978.

[17] K.L. Sahrawat. Iron toxicity in wetland rice and the role of other nutrients. J. Plant Nutr, Vol. 27, 1471-1504, 2004.

[18] D. Baralkiewicz, J. Siepak. Chromium, Nickel and Cobalt in
Environmental Samples and Existing Legal Norms, Polish Journal of Environmental Studies Vol. 8, No. 4 ,201-208,1999.

[19] J.R. Dojlido, G.A. Best. Chemistry of Water and Water Pollution, Ellis Horwood Limited, New York, 1993.

[20] P. J. White, \& P. H. Brown, Plant nutrition for sustainable development and global health. Annals of Botany, Vol. 105, 1073-1080, 2010

[21] S. Sonmez, M. Kaplan, N. K. Sonmez, H. Kaya, \& I. Uz. High level of copper application to soil and leaves reduce the growth and yield of tomato plants. Scientia Agricola, Vol. 63, 213-218, 2006.

[22] WHO (2007), Joint FAO/WHO Expert standards program codex Alimentation Commission. Geneva, Switzerland. Available online http://www.who.int [Accessed 10/09/2012]

[23] B.J. Alloway. Heavy Metals in Soils: Trace Metals and Metalloids in Soils and their Bioavailability. Environmental Pollution, Vol. 22, 2013.

[24] A.L. Edwards. The Correlation Coefficient. Introduction to Linear Regression and Correlation; W. H. Freeman and Company: San Fransisco, CA, USA, Chapter 4, 33-46, 1976. 